\title{
Pemberian Pemahaman Fungsi Pohon bagi Ekosistem untuk Peserta TBM Kolong Jalan Layang Ciputat
}

\author{
Selviana Teras Widy Rahayu \\ Universitas Pamulang \\ Korespondensi: dosen02107@unpam.ac.id
}

\begin{abstract}
The purpose of Community Service Activities is to carry out one of the Tri Dharma. The location of the campus is not far from the location of the Community Reading Park, under the Ciputat Bridge, it has become an obligation for universities to participate in helping various problems faced by the community. It is appropriate for the presence of tertiary institutions to be truly accommodated by the community, in both of sides. The main principle of community empowerment is that groups that are born from the needs and awareness of the community itself are managed and developed using primarily the resources in the community, and have the same goals. Related to instilling children's awareness about the importance of protecting trees and ecosystems for human survival, a learning media that is interesting and can motivate them is very much needed. Learning media that will be used are dioramas and story readings. The knowledge gained in Community Service is expected to be able to take moral lessons that children must aware about the importance of maintaining trees in the ecosystem for future human survival and provide motivation for young people in the family, school and campus environment.
\end{abstract}

Keywords: diorama, ecosystem, maintaining trees.

\begin{abstract}
Abstrak
Tujuan dari Kegiatan Pengabdian Kepada Masyarakat adalah untuk melaksanakan salah satu dari Tri Darma Perguruan Tinggi. Melihat lokasi kampus yang tidak jauh dengan lokasi Taman Bacaan Masyarakat, Kolong Jembatan Ciputat, maka sudah menjadi kewajiban bagi perguruan tinggi untuk ikut serta membantu berbagai persoalan yang dihadapi masyarakat. Sudah selayaknya kehadiran perguruan tinggi agar dapat benar-benar dirasakan manfaatnya oleh masyarakat baik yang dekat maupun yang jauh. Prinsip pemberdayaan masyarakat yang paling baik adalah kelompok yang memang lahir dari kebutuhan dan kesadaran masyarakat sendiri dikelola dan dikembangkan dengan menggunakan terutama sumber daya yang ada di masyarakat tersebut, dan memiliki tujuan yang sama. Terkait menanamkan kepedulian anak-anak tentang pentingnya menjaga pohon dan ekosistem demi keberlangsungan hidup manusia, sebuat media pembelajaran yang menarik dan dapat memotivasi mereka sangat diperlukan. Media pembelajaran yang akan digunakan adalah diorama dan pembacaan cerita. Ilmu yang diperoleh pada Pengabdian Kepada Masyarakat diharapkan mampu mengambil pelajaran moral yang harus diketahui anak-anak tentang pentingnya memelihara pohon di dalam ekosistem demi keberlangsungan hidup manusia di masa yang akan datang dan memberikan motivasi bagi generasi muda baik di lingkungan keluarga, sekolah dan kampus.
\end{abstract}

Kata kunci: diorama, ekosistem, merawat pohon. 


\section{A. Pendahuluan}

Pepohonan adalah bagian dari kehidupan dan keberlangsungan peradaban manusia. Bayangkan bumi tanpa pohon. Namun makin hari keberadaan pohon makin diabaikan. Penebangan hutan, perusakan lingkungan, dan eksploitasi besarbesaran makin menyingkirkan pohon. Kita butuh pohon, tapi kita hanya tahu memanfaatkannya, tanpa banyak yang tahu merawatnya, menjaga keberlangsungan keturunan darinya. Saat ini Indonesia dalam kondisi memprihatinkan karena pernah dinyatakan dalam Guiness Book of Record sebagai negara nomor satu dalam perusakan hutan.

Kondisi yang sangat memprihatinkan bukan? Padahal keberadaan hutan sangatlah penting sebagai paru-paru dunia, dan menjaga agar tidak terjadi perubahan iklim yang drastis. Pepohonan dan hutan pun sangat penting untuk menjaga lingkungan hidup bagi flora dan fauna, menjaga kesuburan tanah, dan rangkaian ekosistem yang penting bagi kehidupan manusia, disamping sebagai alat menabung, untuk air. Menjaga hutan berarti menjaga pohon. Menjaga pohon berarti belajar mencintai pohon. Tidak hanya untuk kehidupan manusia saat ini, namun juga untuk anak cucu kita nanti. Lalu bagaimana kita dapat menjaga keberlangsungan kehidupan pohon, mencintai pohon serta menabung pohon untuk generasi yang akan datang? Lemahnya penegakan hukum memunculkan kepirihatinan masyarakat. Oleh karena itu, pemerintah harus memperbaiki kinerja penegakan hukum yaitu aparat penegak hukum dalam menangani tindak pidana di bidang kehutanan yang lainnya. Pemerintah harus konsisten dalam menegakkan hukum terhadap setiap pelaku pelanggaran hukum di bidang kehutanan. Selain hutan pengaturan penanaman hutan kota dan taman-taman dalam kota dan di daerah-daerah pun ditegaskan kembali, sehingga tidak ada lagi pengalihdayaan hutan dan ruang terbuka untuk kepentingan komersial yang hanya menguntungkan segelintir manusia. Kebanyakan pepohonan yang ada di perkotaan pun tidak dirawat dengan semestinya. Perusakan pohon berupa vandalisme, pemasangan paku-paku untuk poster dan spanduk, pembakaran di dekat pohon, dapat merusak pohon sehingga membuat keropos di dalam sehingga mudah rubuh dan patah. Ketidakpedulian masyarakat yang mementingkan fungsi komersial daripada pentingnya pohon dengan masih adanya penebangan untuk lahan bisnis dan parkir masih kerap terjadi. Kuncinya, kemampuan pemerintah daerah merawat pesona ekologi dan pesona ekonomi hutan serta tata ruang itu sehingga sesuai manfaat keberadaannya betul-betul terasakan terutama para anggota masyarakat yang tinggal di sekitarnya. Masyarakat membutuhkan pendampingan dan dukungan lembaga-lembaga swadaya masyarakat yang peduli lingkungan, niscaya upaya pelestarian lingkungan bukan tindakan yang sia-sia. Menggali dan menghidupkan kembali kearifan lokal kita adalah bangsa yang memiliki leluhur dengan banyak kearifan lokal dan budaya yang mencintai lingkungan hidup. Dalam UU No. 32 Tahun 2009 tentang Perlindungan dan Pengelolaan Lingkungan Hidup pasal 70 disebutkan bahwa masyarakat memiliki hak dan kesempatan yang seluas-luasnya untuk berperan aktif dalam perlindungan dan pengelolaan lingkungan hidup. Untuk itu setiap orang, baik orang perseorangan maupun badan usaha yang berbadan hukum maupun tidak, sebagai anggota dari masyarakat itu sendiri, sudah semestinya memiliki kesadaran dan dapat menerapkan perlindungan dan 
mengelola lingkungan hidup secara bijaksana untuk kehidupan yang lebih baik, saat ini maupun untuk generasi yang akan datang.

Ekosistem adalah "tatanan dari satuan unsur-unsur lingkungan hidup dan kehidupan (Biotik maupun Abiotik) secara utuh dan menyeluruh yang saling mempengaruhi dan saling tergantung dengan yang lainnya. Ekosistem mengandung keanekaragaman jenis dalam suatu komunitas dengan lingkungannya yang berfungsi sebagai suatu satuan interaksi kehidupan dalam alam" (Departemen Kehutanan, 1997). Ekosistem adalah "unit fungsional dasar dalam ekologi yang didalamnya tercakup organisme dan lingkungannya (lingkungan abiotik dan biotik) dan diantara keduanya saling memengaruhi" (Odum, 1993). Permasalahan tersebut juga dirasakan oleh anak-anak yang ada di Kolong jembatan Ciputat di Taman Bacaan Masyarakat. Dulu tempat ini sebagai pos Satuan Polisi Pamong Praja dan sekarang disulap menjadi perpustakaan mini. Taman Bacaan Masyarakat/ TBM Kolong Ciputat dimulai pada tahun 2017 didirikan oleh para pejuang pendidikan dari komunitas mahasiswa.

Pengelola TBM adalah dari Komunitas Fisip Mengajar, dengan memanfaatkan sebuah bangunan terbengkalai di bawah kolong jalan layang Ciputat. Mereka mengembangkan taman bacaan menjadi program pendidikan swadaya masyarakat tanpa donasi.Dukungan dari pemprov Tangsel hanya sebatas memfasilitasi tempat dan ornamen taman bermain untuk anak-anak. Banyak orang tua membawa anaknya ke Taman Bacaan Kolong, fly over Ciputat, Tangerang Selatan. Di sana anak-anak yang belajar bersama dengan komunitas Taman Baca Masyarakat/ TBM berasal dari anak pedagang kaki lima, depan Pasar Ciputat dan masyarakat sekitar. Mereka ingin sekali menjaga lingkungan nya dengan menjaga lingkungan nya seperti pohon dan ekositem yang ada di sekeliling mereka. Berdasarkan hasil obsevasi yang dilakukan sebelum kegiatan PKM dilaksanakan, terdapat masalah yang dihadapi oleh anak-anak kurangnya pengetahuan atau penyuluhan bagaimana menyadari pentingnya memelihara pohon dan ekosistem untuk kehidupan manusia yang akan datang di sekitar lingkungan tersebut.

Berdasarkan latar belakang tersebut, kami dari tim Program Pengabdian Masyarakat (PKM), Universitas Pamulang (Unpam) yang berjumlah 4 dosen dan 12 mahasiswa/i untuk ikut serta membantu memberikan pengetahuan dalam menjaga lingkungan hidup.

\section{Teknik Membaca}

Membaca adalah "suatu proses yang dilakukan serta dipergunakan oleh seseorang untuk memperoleh pesan yang hendak disampaikan oleh penulis melalui media kata-kata atau media tulis" (Tarigan \& Guntur, 1986, p. 7). Membaca dapat pula dianggap sebagai suatu proses memahami makna yang tersurat maupun tersirat dalam suatu bacaan. Belajar sebenarnya mengandung arti bagaimana kita menerima informasi dari dunia sekitar kita dan bagaimana kita memproses dan menggunakan informasi tersebut. Mengingat setiap individu memiliki keunikan tersendiri dan tidak pernah ada dua orang yang memiliki pengalaman hidup yang sama persis, hampir dipastikan bahwa "gaya belajar" masing-masing orang berbeda satu dengan yang lain. Namun, di tengah segala keragaman "gaya belajar" tersebut, banyak ahli mencoba menggunakan klasifikasi 
atau pengelompokan 'gaya belajar" untuk memudahkan kita semua, khususnya para guru dalam menjalankan tugas pendidikan dengan lebih strategis. Membaca pada hakikatnya adalah "suatu yang rumit melibatkan banyak hal, tidak hanya sekedar melafalkan tulisan, tetapi juga melibatkan aktivitas visual, berpikir, psikolinguistik, dan metakognitif" (Rahim, 2008).

\section{Teori Ekosistem}

Ekosistem merupakan semua organisme pada daerah tertentu berikut faktorfaktor abiotik yang berinteraksi dengan organisme satu atau beberapa komunitas dan lingkungan fisik di sekitarnya (Champbell, 2010, p. 327). Dapat disimpulkan bahwa ekosistem merupakan interaksi makhluk hidup dengan lingkungannya, hubungan saling ketergantungan antara makhluk hidup dengan lingkungannya, hubungan timbal balik antara makhluk hidup dengan lingkungan fisiknya, tumbuhan, hewan, dan lingkungan membentuk sebuah ekosistem. Di dalam ekosistem makhluk hidup mampu memenuhi kebutuhannya. Di sawah, kolam, kebun, sungai, danau, dan laut, berbagai makhluk hidup tinggal bersama. Sawah, kolam, kebun, sungai, danau dan laut adalah beberapa bentuk ekosistem.Keseimbangan Ekosistem Keseimbangan ekosistem dapat dipengaruhi oleh beberapa faktor diantaranya:

1) Bencana alam, misalnya: gunung meletus, tanah longsor, banjir, dan gempa bumi. Bencana alam dapat menyebabkan terjadinya perubahan lingkungan. Misalnya lingkungan perumahan rusak, manusia banyak yang mati, hewan dan tanaman juga banyak yang mati.

2) Ulah manusia.

Keseimbangan ekosistem yang disebabkan oleh ulah manusia misalnya pencemaran air dan penebangan hutan secara liar.

a) Pencemaran air.

Pencemaran air di sungai dapat menyebabkan kehidupan hewan dan tumbuhan terganggu.

b) Penebangan hutan liar. Penebangan hutan secara liar menyebabkan terjadinya banjir dan hewan akan kehilangan tempat tinggal (Haryanto, 2012).

\section{Media Diorama}

Salah satu permasalahan dalam pembelajaran tematik dari adanya kurikulum 2013 adalah banyak diantara siswa yang mengalami kesulitan dalam menyerap pembelajaran dan guru tidak menggunakan media dalam proses pembelajaran sehingga tidak ada sesuatu yang dapat membuat siswa tertarik dalam melakukan proses pembelajaran, sehingga hasil belajar yang diperoleh siswa kurang dari ratarata. Dengan menggunakan media diorama dapat dimanfaatkan untuk membantu meningkatkan minat dan hasil belajar siswa. Tujuan penelitian ini adalah untuk mengetahui hasil belajar siswa pada tema ekosistem dengan menggunakan media diorama. Metode yang digunakan adalah penelitian eksperimen semu dengan desain non equivalent control group design. Data yang telah terkumpul dianalisis menggunakan teknik analisis kuantitatif. Hasil dari penelitian menunjukkan bahwa dengan penggunaan media diorama dapat meningkatkan hasil belajar 
siswa. Dengan demikian materi ekosistem dapat diajarkan dengan menggunakan media diorama. (Lestari, 2017). Media diorama merupakan gambaran kejadian yang disajikan dalam bentuk mini atau kecil. Media diorama sangat efektif dan tepat untuk pemilihan media pembelajaran khususnya materi ekosistem karena media diorama merupakan gambar perspektif dalam suatu penampilan utuh yang menggambarkan suasana sebenarnya (Kustandi, 2013).

\section{Metode Pengajaran}

Dalam metode pengajaran ada dua aspek yang paling menonjol yakni; "metode mengajar dan media pengajaran sebagai alat bantu pengajaran sedangkan penilaian adalah alat untuk mengukur atau menentukan taraf tercapai tidaknya tujuan pembelajaran" (Sudjana dan Rifa'i, 2002). Pendidikan "adalah usaha manusia untuk membina kepribadiannya sesuai nilai-nilai yang ada di dalam masyarakat dan kebudayaan. Sedangkan secara luas, pendidikan adalah segala pengalaman belajar yang berlangsung di segala lingkungan dan sepanjang hidup" (Mudyharto, 2012). Sarana dan alat pendidikan merupakan faktor dalam pendidikan memiliki peran yang penting untuk keberhasilan proses belajar mengajar. Keberadaan media akan lebih membantu secara cepat tercapainya tujuan secara efektif dan efisien para guru dituntut agar mampu menggunakan alat-alat yang telah disediakan oleh sekolah dan alat-alat tersebut sudah sesuai dengan perkembangan zaman saat ini. Pada hakekatnya kegiatan belajar mengajar adalah satu proses komunikasi, proses komunikasi ini harus diwujudkan melalui kegiatan penyampaian dan tukar menukar pesan atau informasi oleh setiap guru dan peserta didik. Pesan atau informasi pendidikan dapat berupa pengetahuan, keahlian, pengalaman dan sebagainya. Melalui komunikasi pesan dimungkinkan bisa diserap oleh semua orang. Demikian halnya dalam proses komunikasi perlu digunakan sarana dalam proses mengajar yang membantu proses komunikasi yang disebut media (Rihani, 1991). Dalam dunia pendidikan komunikasi merupakan ruh dari keberlangsungan pendidikan itu sendiri. Tanpa ruh komunikasi yang baik, pendidikan akan kehilangan cara dan orientasi dalam pencapaian kualitas yang diharapkan. Pembelajaran adalah suatu kombinasi yang tersusun meliputi unsurunsur manusiawi, material, fasilitas, perlengkapan dan prosedur yang saling mempengaruhi untuk mencapai tujuan pembelajaran (Hamalik, 2005). Jadi, pembelajaran adalah hubungan antara pihak pengajar dan pihak yang diajar sehingga tercipta suasana pihak siswa aktif belajar dan pihak guru aktif mengajar tidak hanya salah satu pihak saja yang aktif, tetapi melibatkan kedua belah pihak.

\section{B. Pelaksanaan dan Metode}

Sasaran kegiatan Pengabdian Kepada Masyarakat ini yang dituju adalah anak-anak tingkat TK, SD dan SMP yang beralamatkan di Jalan Dewi Sartika Ciputat, Taman Bacaan Masyarakat, Kolong Jembatan Ciputat, Tangerang Selatan yang dilaksanakan pada hari Jumat, Sabtu, dan Minggu, tanggal 08-10 November 2019. Tujuan mendasar yang ditawarkan oleh kegiatan Pengabdian Kepada Masyarakat ini adalah menanamkan kepedulian anak-anak Taman Baca Masyarakat Kolong Jembatan Ciputat terhadap pemeliharaan pohon dan ekosistem demi keberlangsungan hidup manusia di masa yang akan datang. 
Dalam PKM ini menggunakan prosedur melalui teknik pengajaran pembacaan cerita dan diorama. Melalui kegiatan PKM ini penulis bertujuan untuk membantu anak-anak yang berada di Taman Bacaan Kolong Jembatan Ciputat dalam menyadari pentingnya memelihara lingkungan hidup.

Metode pendekatan mengajarkan kepedulian terhadap pentingnya memelihara pohon di dalam ekosistem pada anak-anak membutuhkan strategi terencana agar membuat mereka tertarik, termotivasi untuk belajar, dan mau mendengarkan materi yang akan disampaikan. Untuk menyelesaikan masalah yang dihadapi mitra penulis menggunakan strategi untuk realisasi pemecahan masalah. Salah satu cara agar perhatian mereka terpusat pada pembelajaran adalah penggunaan alat-alat pembelajaran atau media pembelajaran. Media digunakan agar pembelajaran dapat efektif dan menyenangkan. Ibrahim dkk (2006) menyatakan bahwa media pembelajaran adalah segala sesuatu yang dapat digunakan untuk menyalurkan pesan (bahan pembelajaran) sehingga dapat merangsang perhatian, minat, pikiran, dan perasaan siswa dalam kegiatan belajar untuk mencapai pembelajaran tertentu. Salah satu alat atau media pembelajaran yang dapat digunakan adalah diorama. Berdasarkan Kamus Besar Bahasa Indonesia (2009), "sajian pemandangan dalam ukuran kecil yang dilengkapi dengan patung dan perincian lingkungan seperti aslinya serta dipadukan dengan latar yang berwarna alami; pola atau corak tiga dimensi suatu adegan atau pemandangan yang dihasilkan dengan menempatkan objek dan tokoh di depan latar belakang dengan perspektif yang sebenarnya sehingga dapat menggambarkan keadaan yang sebenarnya". Jadi, dapat disimpulkan bahwa diorama adalah suatu kotak yang di dalamnya berisi tiruan pemandangan atau suatu benda yang lengkap dengan sesuatu yang berada di sekitarnya. Kesemuanya tersebut dibuat lebih kecil daripada keadaan aslinya.

Diorama biasanya digunakan dalam menggambarkan kejadian dan atau suatu proses supaya yang melihatnya tertarik untuk memahami isi tersebut. Sebagai media pembelajaran, diorama dianggap bisa memvisualisasikan lingkungan dan isinya agar anak anak di Taman Baca Masyarakat Kolong Jembatan Ciputat yang belum mampu diajak berfikir secara kritis bisa mempelajari materi dengan lebih mudah. Penggunaan diorama menjadi salah satu cara yang akan diterapkan dalam pelaksanaan Pengabdian Kepada Masyarakat di Taman Baca Masyarakat Kolong Jembatan Ciputat.

Detail prosedur pelaksanaan kegiatan Pengabdian Kepada Masyarakat adalah sebagai berikut:

1. Pembukaan Ketua Tim kegiatan Pengabdian Kepada Masyarakat membuka kegiatan.

2. Membagi tim dan anak-anak menjadi beberapa kelompok.

3. Mengenalkan cerita.

4. Membacakan cerita atau mendongeng.

5. Memahami cerita.

6. Mempraktekan cerita menggunakan diorama.

7. Menanyakan cerita atau mendiskusikan kosakata.

8. Mendiskusikan pesan atau nilai moral dari teks.

9. Memberikan model kepada anak-anak. 
http://openjournal.unpam.ac.id/index.php/ACB/issue/view/605/showToc

10. Menggunakan flash-card card untuk mengenalkan kosakata baru dengan memberikan kesempatan kepada anak-anak untuk menebak.

\section{Hasil dan Pembahasan}

Dalam Kegiatan Pengabdian Kepada Masyarakat di Taman Bacaan Masyarakat, Jembatan Kolong Ciputat selama 3 hari ini kami mendapatkan penemuan setelah melakukan interaksi langung dengan mengajukan pertanyaan langsung kepada mereka dan melakukan pengamatan. Deskripsi dari penemuan tersebut antara lain:

\section{Hasil}

\section{Pembentukan Karakter Anak}

Peserta kegiatan Pengabdian Kepada Masyarakat yang berlokasi di Taman Bacaan Masyarakat, Kolong Jembatan Ciputat ini terdiri dari anak-anak yang masih berkisar antara lain:

1. Kerja sama dalam tim

Manusia dilahirkan sebagai makhluk sosial dimana dalam kehidupannya akan berinteraksi sosial dengan lainnya, sehingga diperlukan sikap saling menghargai satu sama lain agar tidak bersinggungan. Sehingga lingkungan berpengaruh besar untuk mengajarkan anak mengenai kerjasama dalam berbagai aspek dengan menjunjung kebersamaan. Dalam kegiatan PKM ini kami menemukan beberapa hal ketika anak saling bekerja sama antara lain:

Tabel 1. Kerjasama dalam Tim

\begin{tabular}{|l|l|l|}
\hline No. & \multicolumn{1}{|c|}{ Kegiatan } & \multicolumn{1}{c|}{ Bentuk Kerjasama } \\
\hline 1 & $\begin{array}{l}\text { Mendistribusikan permainan dalam } \\
\text { bentuk puzzle untuk menyusun pohon }\end{array}$ & $\begin{array}{l}\text { Peserta PKM mampu berkerjasama } \\
\text { dengan timnya dengan baik untuk } \\
\text { menyelesaikan tugasnya. }\end{array}$ \\
\hline 2 & $\begin{array}{l}\text { Mendistribusikan gambar bagian- } \\
\text { bagian pohon untuk ditempelkan di } \\
\text { pohon yang sudah beerbentuk utuh }\end{array}$ & $\begin{array}{l}\text { Peserta PKM mampu membagi tugas } \\
\text { mereka tanpa berebutan dan } \\
\text { memahami tugasnya dengan baik. }\end{array}$ \\
\hline 3 & $\begin{array}{l}\text { Penulis membagikan foto-foto para } \\
\text { pahlawan bangsa dan meminta mereka } \\
\text { menceritakan tentang pahlawan yang } \\
\text { mereka ketahuidan meminta peserta } \\
\text { PKM memberikan pertanyaan tentang } \\
\text { kewajiban mereka sebagai generasi } \\
\text { penerus }\end{array}$ & $\begin{array}{l}\text { Peserta PKM mampu menceritakan } \\
\text { pahlawan yang mereka ketahui dan } \\
\text { mereka mempunyai cita-cita ingin } \\
\text { seperti pahlawan bangsa yang berguna } \\
\text { bagi bangsanya. }\end{array}$ \\
\hline
\end{tabular}

2. Kesadaran untuk menjaga kelestarian lingkungan.

Menumbuhkan kesadaran anak memang paling efektif ketika ditanamkan sejak usia dini karena mereka mudah meniru apa yang sudah diajarkan oleh orang tua ataupun gurunya sehingga diperlukan lingkungan dan peran orang tua yang 
http://openjournal.unpam.ac.id/index.php/ACB/issue/view/605/showToc

dapat membimbing anak aagar menjadi anak yang memiliki tingkat kepedulian terhadap lingkungan sekitarmya.

Tabel 2. Kesadaran untuk Menjaga Kelestarian Lingkungan

\begin{tabular}{|l|l|l|}
\hline No. & \multicolumn{1}{|c|}{ Kegiatan } & \multicolumn{1}{c|}{ Respon Anak } \\
\hline 1 & $\begin{array}{l}\text { Penulis menanyakan : Mengapa } \\
\text { pohon harus dilestarikan }\end{array}$ & $\begin{array}{l}\text { Mereka menjawab pertanyaan : } \\
\text { biar lingkunganya sejuk karena banyak } \\
\text { pohon. }\end{array}$ \\
\hline 2 & $\begin{array}{l}\text { Penulis menanyakan : Agar pohon } \\
\text { tidak abis apa yang kalian lakukan }\end{array}$ & Agar tersedia mata air. \\
\hline 3 & $\begin{array}{l}\text { Penulis menanyakan : Untuk } \\
\text { menghormati jasa para pahlawan } \\
\text { adalah menjaga } \\
\text { lingkungan agar anak cucu kalian } \\
\text { merasakan lingkungan yang } \\
\text { terjaga, apa yang kalian lakukan } \\
\text { untuk mengenang jasa pahlawan } \\
\text { tsb }\end{array}$ & $\begin{array}{l}\text { Menanaman tanaman di pot } \\
\text { manfaat menjaga kelestarian alam adalah } \\
\text { wujud cinta kepada pahlawan }\end{array}$ \\
$\begin{array}{l}\text { Mengajarkan kepada sesama tentang } \\
\text { kelsetarian lingkungan agar Indonesia tetap } \\
\text { sejahtera }\end{array}$ \\
\hline
\end{tabular}

\section{Pemerolehan Bahasa Inggris Anak}

Di era yang menuju revolusi industri 4 ini kita semua dihadapkan agar mampu mengikuti globalisasi tentunya ditunjang dengan penguasaan Bahasa Inggris sejak dini agar anak lebih mudah memahaminya karena Bahasa Inggris bukan hal yang mudah karena tidak diterapkan dalam kehidupan sehari-hari kita. Untuk memberikan pemahaman yang tepat dapat ditunjang dengan menggunakan media pembelajaran yang tepat sehingga dapat mudah mengingatnya seperti penggunaan media diaroma ini. Dari interaksi kami dengan anak-anak peserta PKM kami memperoleh penemuan pemerolehan Bahasa Inggris anak antara lain: 
http://openjournal.unpam.ac.id/index.php/ACB/issue/view/605/showToc

Tabel 3. Pemerolehan Bahasa Inggris Anak

\begin{tabular}{|l|l|l|}
\hline No. & \multicolumn{1}{|c|}{ Kegiatan } & Contoh Pemerolehan Bahasa Inggris \\
\hline 1 & $\begin{array}{l}\text { Bekerja sama dengan anak untuk } \\
\text { menyusun puzzle }\end{array}$ & Green \\
Fruit \\
Tree \\
\hline 2 & $\begin{array}{l}\text { Menyebutkan tempat yang } \\
\text { berkaitan dengan menanam pohon }\end{array}$ & School \\
House \\
\hline
\end{tabular}

\section{Pembahasan}

Kesadaran akan menjaga lingkungan sekitar dengan menjaga kelestarian pepohonan masih minim sekali di lingkungan anak-anak peserta PKM tersebut karena faktor dari orang tua dan minimnya wawasan yang mereka peroleh sehingga untuk terciptanya kondisi yang diinginkan diperlukan penyuluhan secara bertahap agar mereka pham betul manfaat dari menanam pohon bagi lingkungan dan partisipasi sebagai generasi muda untuk melanjutkan perjuangan pahlawan pendahulu kita, karena kalau bukan kita siapa lagi.

Di sisi lain terdapat penemuan yang berbeda dimana ada anak yang mengerti benar dan menerapkannya dalam kehidupan sehari-hari karena sudah mendapatkan pengetahuan di bangku sekolahnya dan didukung dengan orang tuanya yang memang hobi menanam tanaman. Dari situ akhirnya anaknya meniru yang menjadi kebiasaan orang tuanya sehari-hari. Dalam waktu 3 hari tersebut ada anak yang antusias langsung menanam pohon di rumahnya, hal itu dilakukan oleh anak yang sudah berumur 12 tahun, sedangkan untuk anak yang masih di usia kisaran 5 tahun mereka sepulangnya banyak menanyakan isi dari penyuluhan kepada orang tuanya. Orang tuanya ada yang langsung merespon dengan mengajarkan anaknya menanam dan ada yang tidak merespon karena memang mereka terdiri dari latar belakang keluarga yang beraneka ragam.

\section{Penutup \\ Simpulan}

Setelah kami mengadakan kegiatan Pengabdian Kepada Masyarakat di Taman Bacaan Masyarakat, Kolong Jembatan Ciputat, Tangerang Selatan ini, kami menyimpulkan bahwa anak-anak ketika mengikuti proses pembelajaran selama 3 hari, mereka cepat memahami Bahasa Inggris dengan menggunakan media diorama yang kami gunakan karena dengan bentuknya yang menarik mengundang minat belajar anak dan mudah untuk diingat. Media diorama bentuknya sama dengan yang ada di alam sekitar sehingga mereka berantusias sekali untuk hadir di program selanjutnya. Selain itu, kami lebih mudah menyampaikan pesan moral yang berkaitan dengan upaya melestarikan 
lingkungan dengan pepohonan. Anak-anak dapat menyadari fungsi dari adanya pohon sebagai wujud generasi muda menjaga ekosistem alam untuk keberlangsungan hidup bersama. Dengan penyuluhan ini kami melihat adanya rasa saling mnghargai ketika mereka bekerja sama dalam pembelajaran secara kelompok sehingga sejak dini mereka diajarkan rasa toleransi, selain itu menumbuhkan rasa berbagi kepada sesama karena mereka memakai media pembelajaran bersama sehingga bisa saling bergantian.

\section{Saran}

Penulis berharap dengan adanya kegiatan Pengabdian Kepada Masyarakat ini orang tua dan koordinator Taman Bacaan Masyarakat dapat lebih memberikan perhatian yang intensif kepada anak-anak mengenai aktivitas sehari-hari mereka baik langsung maupun tidak langsung supaya mudah mengawasi mereka agar selalu masuk ke dalam kegiatan yang positif. Selain itu, orang tua sebagai orang terdekat anak harus selalu membimbing anak dan mengajarkan hal yang bermanfaat sebagai bekal hidup mereka selanjutnya. Lingkungan sekitar juga harus memberikan nuansa yang mendukung bagi tumbuh kembang mereka agar menjadi generasi penerus yang berguna bagi nusa dan bangsa karena seumuran mereka lebih suka meniru apa yang diajarkan orang tua dan guru.

\section{DAFTAR PUSTAKA}

Champbell, \& Neil, A. (2010). Biologi. Jakarta: Erlangga.

Hamalik, O. (2005). Kurikulum dan Pembelajaran. Jakarta: PT. Bumi Aksara.

Haryanto. (2012). SAINS Jilid 4 untuk Kelas IV. Jakarta: Erlangga.

Kustandi, C. (2013). Media Pembelajaran Manual dan Digital. Bogor: GhaliaIndonesia.

Lestari, T. (2017). Pengaruh Penggunaan Media Diorama Terhadap Hasil Belajar Siswa Kelas V Pada Tema Ekosistem di Sekolah Dasar. Diakses dari http://jurnalmahasiswa.unesa.ac.id

Mudyharto, R. (2012). Filsafat Ilmu Pendidikan. Bandung: PT Remaja Rosdakarya.

Odum, E.P. (1993). Dasar-Dasar Ekologi. Yogyakarta: Gadjah Mada University Press.

Rahim, F. (2008). Pengajaran Membaca di Sekolah Dasar. Jakarta: Bumi Aksara. Rihani, A. (1991). Media Intruksional Efektif. Jakarta: Rineka Cipta.

Sudjana, N., \& Rifa'I, A. (2002). Media Pengajaran. Bandung: Sinar Guru Algesindo.

Tarigan, H. G. (1986). Membaca Sebagai Suatu Keterampilan Berbahasa. Bandung: Angkasa. 